\title{
Application of Ion-Association Titration for the Assay of Cyproheptadine Hydrochloride in Pharmaceuticals
}

\author{
Madihalli S. Raghu and kanakapura Basavaiah \\ Department of Chemistry, University of Mysore, Manasagangotri, Mysore 570006, India \\ Correspondence should be addressed to kanakapura Basavaiah, basavaiahk@yahoo.co.in
}

Received 23 December 2011; Accepted 19 January 2012

Academic Editors: H. Alemu, M. Mazloum-Ardakani, A. Orte, and B. Rittich

Copyright ( $) 2012$ M. S. Raghu and k. Basavaiah. This is an open access article distributed under the Creative Commons Attribution License, which permits unrestricted use, distribution, and reproduction in any medium, provided the original work is properly cited.

\begin{abstract}
Two simple and rapid titrimetric methods are described for the determination of cyproheptadine hydrochloride (CPH) in pharmaceuticals. The proposed methods are based on the solvent extraction-titration of CPH with two ion association reagents, sodium lauryl sulphate (SLS), (method A), and tetraphenylborate (TPB), (method B). In method A, SLS was used as titrant and the titration was carried out in the presence of dilute sulphuric acid and chloroform using dimethyl yellow as indicator, whereas, in method B, the titrant was TPB and the titration was done in Walpole buffer of $\mathrm{pH} 4.5$ and 1,2-dichloroethane using tetrabromophenolphthalein ethyl ester as indicator. The proposed procedures give sharp end points as the color of the organic phase changes from yellow to pink in method A, and from red-violet to yellow in method $\mathrm{B}$. The methods are applicable over the ranges of 1.0-20.0 and 2.0-9.0 mg of CPH for method A and method B, respectively. The accuracy and precision of the methods are good. The methods were applied successfully to the determination of $\mathrm{CPH}$ in tablets, and the results were in agreement with the label claim and those of the reference method.
\end{abstract}

\section{Introduction}

Cyproheptadine hydrochloride (CPH), chemically known as 4-(5Hdibenzo [a,d]-cyclohepten-5-ylidene)-1-methylpiperidine hydrochloride (Figure 1), is a sedating antihistamine with antimuscarinic, serotonin-antagonist, and calciumchannel blocking action in pancreatic islet cells and smooth muscle [1]. It is used to treat some hormonal disorders and may also be used for treating side effects of taking antidepressants [2].

The drug is official in Indian Pharmacopeia [3] which describes a UV-spectrophotometric method for its assay in tablet. The United Sates Pharmacopeia [4] describes nonaqueous titration with perchloric acid as titrant where the end point is located visually using crystal violet as indicator. Literature survey revealed the availability of few methods for the assay of $\mathrm{CPH}$ in pharmaceutical formulations. Liquid chromatography-mass spectrometry (LC-MS) [5], gas liquid chromatography $[6,7]$, and high performance liquid chromatography (HPLC) [8-14] have been used to assay $\mathrm{CPH}$. Recently, HPLC has been used for the assay of $\mathrm{CPH}$ in feed stuff [15]. Application of visible spectrophotometric methods [16-23], derivative UV-spectrophotometry for the assay of $\mathrm{CPH}$ in two-component system [24] has also been reported. Ion-selective-based potentiometry is another technique which has found application in the analysis of $\mathrm{CPH}$-containing tablets. The drug has been assayed by potentiometry using $\mathrm{CPH}$-tetraphenylborate [25], CPHdinonylnaphthalene sulphonic acid [26], CPH-tetrakis(4chlorophenyl)borate [27] as electroactive compounds.

Liu and Lü [28] developed chemiluminescence method for the determination of $\mathrm{CPH}$, where riboflavin was used as chemiluminescence reagent. Feng and Guo [29] reported a method for the assay of $\mathrm{CPH}$ in serum, urine and in pharmaceuticals based on the measurement of enhancement of resonance light scattering at $364 \mathrm{~nm}$ after formation of ionassociation complex with ammonium molybdate.

Other than official method [4], there is a report on the titrimetric assay of $\mathrm{CPH}$ [23], in which the drug is treated with known excess of bromate-bromide mixture in $\mathrm{HCl}$ medium followed by the determination of unreacted bromine iodometrically, and the method is reported to be 


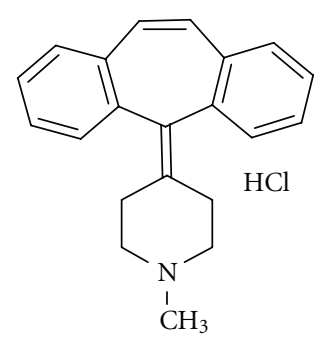

FIGURE 1: Structure of cyproheptadine hydrochloride.

applicable over $2-15 \mathrm{mg}$ range. In the same article, kinetic and visible spectrophotometric assay $\mathrm{CPH}$ is also described changed to and visible spectrophotometric assay of $\mathrm{CPH}$ is also described.

Most reported methods are applicable only over the microgram and nanogram levels and the assay procedure for the determination of $\mathrm{CPH}$ in milligram level is of paramount importance in large scale analysis. Therefore, highly precise stoichiometric reaction with a reagent possessing antagonistic properties for the assay of pharmaceutical using titrimetric procedure is still the choice of many pharmacopoeias $[4,30]$.

Two phase titrations (ion-pair extraction titrations or ion association titrations) employing indicators for visual endpoint detection are already well established for the determination of pharmaceutical substances [31-37]. The characteristic of the ion association titration methods consists in the use of a two-phase (water-organic solvent) system. The end point detection is based on the different stabilities of the ion associations formed between the determined substance with the titrant and with the indicator [34].

This paper presents two ion association titration methods for the determination of $\mathrm{CPH}$ in pharmaceuticals. The methods employ sodium lauryl sulphate (SLS) or sodium tetraphenylborate (NaTPB) as the titrant with the determinations being carried out in the presence of sulphuric acidchloroform or Walpole buffer of $\mathrm{pH}$ 4.5-1, 2-dichloroethane with dimethyl yellow or tetrabromophenolphthalein ethyl ester as the indicator. The methods allow a quick determination of $\mathrm{CPH}$ in bulk drug and in tablets without requiring pretreatment of the sample, with high accuracy and precision, and without interference from excipients.

\section{Materials and Methods}

2.1. Apparatus. Elico LI 610 digital $\mathrm{pH}$ meter provided with a combined glass-SCE electrode system was used to record the $\mathrm{pH}$ and Equip-Tronics magnetic stirrer model EQ-770 was used to carry out the titration successfully.

2.2. Reagents and Materials. All chemicals used were of analytical reagent grade and distilled water was used throughout. A stock standard solution containing $2.0 \mathrm{mg} \mathrm{mL}^{-1}$ of pharmaceutical grade cyproheptadine hydrochloride (Cipla India Ltd, Bangalore.) solution was prepared in water and used in method $\mathrm{A}$, and the same was diluted to $1.0 \mathrm{mg} \mathrm{mL}^{-1}$ with water for use in method B.
A 0.008 M sodium lauryl sulfate (Loba Chemie PVT. Ltd., Mumbai, India, assay 99\%) was prepared in water and standardized using benzethonium chloride [38], 0.01\% (w/v) dimethyl yellow (DMY) (Rolex Laboratory Reagent, Mumbai, India) was prepared in absolute ethanol and $2 \mathrm{M}$ sulphuric acid was prepared by appropriately diluting concentrated sulfuric acid (Merck, Mumbai, India, Sp. gr. 1.84), with water.

A $0.004 \mathrm{M}$ solution of tetraphenylborate was prepared by dissolving required amount of sodium tetraphenylboron (s.d. fine-chem, Mumbai, India, assay 99.5\%) in $10 \mathrm{~mL}$ water and diluting to $250 \mathrm{~mL}$ with $0.001 \mathrm{~N}$ sodium hydroxide solution.

$0.2 \%(\mathrm{w} / \mathrm{v})$ potassium salt of tetrabromophenolphthalein ethyl ester (TBPE) (Sigma-Aldrich, Inc., USA) was prepared in absolute ethanol and the Walpole buffer solution of $\mathrm{pH} 4.5$ was prepared by mixing $0.2 \mathrm{M}$ acetic acid solution (Merck, Mumbai, India) with $0.2 \mathrm{M}$ sodium acetate solution (S. d. fine Chem Ltd., Mumbai, India) and adjusting the $\mathrm{pH}$ with $2 \mathrm{M}$ sulphuric acid.

Chloroform and 1,2-dichloroethane (DCE) (both Merck, Mumbai, India) and absolute ethanol were used without any purification.

\subsection{Methods}

2.3.1. Method A. Different aliquots $(0.5-10 \mathrm{~mL})$ of standard $\mathrm{CPH}\left(2 \mathrm{mg} \mathrm{mL}^{-1}\right)$ solution were transferred into a $100 \mathrm{~mL}$ beaker and the volume was adjusted to $20 \mathrm{~mL}$ with water. Two milliliters of $2 \mathrm{M} \mathrm{H}_{2} \mathrm{SO}_{4}, 0.5 \mathrm{~mL}$ of $0.01 \%$ DMY, and $10 \mathrm{~mL}$ of chloroform were added and the mixture was stirred on a magnetic stirrer for $1 \mathrm{~min}$. The mixture was then titrated with $0.008 \mathrm{M}$ SLS with vigorous stirring until a color change from yellow to pink occurs in the organic phase at the endpoint.

A blank titration was also performed and the necessary volume corrections were made. The amount of the drug in the measured aliquot was calculated from

$$
\operatorname{Amount}(\mathrm{mg})=\frac{V M_{w} R}{n},
$$

where $V=$ volume of SLS, $\mathrm{mL} ; M_{w}=$ relative molecular mass of the drug; and $R=$ molarity of the SLS and $n=$ number of moles of SLS reacting with each mole of CPH.

2.3.2. Method B. Different aliquots of the standard solution (2.0-9.0 mL, $1 \mathrm{mg} \mathrm{mL}^{-1}$ ) of pure $\mathrm{CPH}$ were accurately transferred into a $100 \mathrm{~mL}$ beaker and the volume was adjusted to $10 \mathrm{~mL}$ with water. Five milliliters of the Walpole buffer of $\mathrm{pH}$ 4.5, 2 drops of TBPE indicator solution and $10 \mathrm{~mL}$ of DCE were added and mixed well by magnetic stirring. The mixture was titrated against $0.004 \mathrm{M}$ TPB solution with vigorous stirring until the color of the organic phase changes from red-violet to yellow at the end point. It is not necessary to make a blank titration because the color of the organic phase is yellow in the absence of the drug. The amount of drug in the aliquot was calculated from the equation given under method A. 


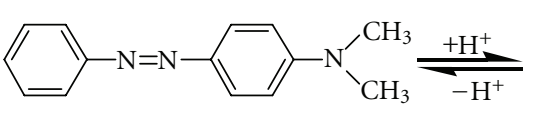

DMY (molecular form) yellow<smiles>CCOC(=O)c1ccccc1C(=C1C=C(Br)C(=O)C(Br)=C1)c1cc(Br)c([O-])c(Br)c1</smiles>

(b) (a)

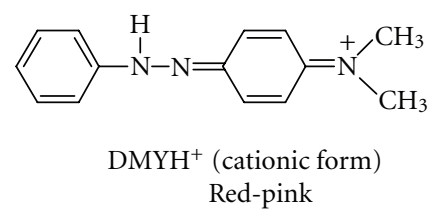<smiles>CCOC(=O)c1ccccc1C(=C1C=C(Br)C(=O)C(Br)=C1)c1cc(C)c(O)c(Br)c1</smiles>

TBPEH (molecular form) yellow

SCHEME 1: Effect of $\mathrm{pH}$ on the indicator color. (a) Dimethyl yellow, (b) tetrabromophenolphthalein ethyl ester.

2.4. Procedure for Tablets. Thirty tablets containing $\mathrm{CPH}$ were weighed accurately and ground into a fine powder. An amount of powder equivalent to $100 \mathrm{mg}$ of $\mathrm{CPH}$ was weighed into a $50 \mathrm{~mL}$ calibrated flask containing about $30 \mathrm{~mL}$ of water. The extraction was done by shaking thoroughly for about $20 \mathrm{~min}$; then the volume was made up to the mark with water, mixed well and filtered using a Whatman no. 42 filter paper. The first $5 \mathrm{~mL}$ portion of the filtrate was discarded in order to avoid small dilution in the concentration of $\mathrm{CPH}$ because of the wetted filter paper. The resulting $(2 \mathrm{mg}$ $\left.\mathrm{mL}^{-1}\right) \mathrm{CPH}$ solution was subjected to titration in method A, following the procedures described above. The solution was diluted with water to get $1 \mathrm{mg} \mathrm{mL}^{-1} \mathrm{CPH}$ and used in method B.

\section{Results and Discussion}

The two-phase ion-association titration was applied to the determination of some basic pharmaceutical compounds using indicators for visible end-point detection. Earlier, the end-point detection in this type of titrations was based on the movement of the indicator from one phase to other and it was difficult to detect the end point because the color of the indicator in the aqueous phase or organic phase will be reflected in the other phase [39].

The use of hydrophobic indicator is an alternative approach, which remains in the organic phase throughout the titration and gives a very sharp color change [40]. Tsubochi et al. [41] used the potassium salt of the ethyl ester of tetrabromophenolphthalein (anionic) indicator in their titration whereas dimethyl yellow (cationic) indicator was used by Eppert and Liebscher [42] for the two-phase titration. The above two indicators are useful in the detection of the end point as the change in color depends on the $\mathrm{pH}$ [31].

\subsection{Method Development}

3.1.1. Method A. This is based on the formation of an ion association complex between the $\mathrm{CPH}$ and the titrant, that is, sodium lauryl sulphate which is used as titrant with dimethyl yellow as indicator in the presence of chloroform. After treating $\mathrm{CPH}$ tertiary amine $\left(\mathrm{R}_{3} \mathrm{~N}\right)$ with $\mathrm{H}_{2} \mathrm{SO}_{4}$, the resulting protonated amine $\left(\mathrm{R}_{3} \mathrm{NH}^{+}\right)$was titrated with sodium lauryl sulphate using DMY. The effects of the acid and the extracting solvent were optimized and it was found that $2 \mathrm{~mL}$ of $2 \mathrm{M} \mathrm{H}_{2} \mathrm{SO}_{4}$ in a total volume of $20 \mathrm{~mL}$ of aqueous phase, and chloroform as solvent $(10 \mathrm{~mL})$, gave a good reproducible and stoichiometric results when compared to 1,2-DCE and dichloromethane (DCM), in the range investigated.

When the mixture of $\mathrm{CPH}$ solution, sulphuric acid, chloroform, and the DMY indicator solution was mixed well, the aqueous phase became colorless, because the indicator itself was not soluble in water, and a yellow color was developed in the chloroform phase, because of the presence of the indicator in a molecular form. When the drug sample was titrated with SLS solution, the protonated drug $\left(\mathrm{R}_{3} \mathrm{NH}^{+}\right)$formed colorless ion association complex $\left(\mathrm{R}_{3} \mathrm{NH}^{+}-\right.$Titrant $\left.^{-}\right)$which will be extracted into the organic phase. When the equivalence point was reached and one drop excess of the titrant was added, the color of organic phase changed from yellow to pink due to the formation of cationic form of DMY indicator, that is, $\mathrm{DMYH}^{+}$Scheme 1, which is stabilized by the formation of stable ion-pair complex with the titrant $\left[\mathrm{DMYH}^{+} \cdot \mathrm{SLS}^{-}\right]$in the organic phase.

The chemical reactions which form the basis for this method can be formulated as follows

Before the addition of titrant:

$$
\begin{aligned}
& \mathrm{R}_{3} \mathrm{NH}^{+} \text {(colorless) }+\mathrm{DMY}_{\mathrm{aq}} \text { (yellow) } \\
& \stackrel{\text { chloroform }}{\longrightarrow} \mathrm{R}_{3} \mathrm{NH}^{+} \text {aq }+\mathrm{DMY}_{\text {org }} \text { (yellow) } .
\end{aligned}
$$

Before the equivalence point:

$\mathrm{R}_{3} \mathrm{NH}^{+}{ }_{\mathrm{aq}}+\mathrm{SLS}^{-}{ }_{\mathrm{aq}} \longrightarrow\left[\mathrm{R}_{3} \mathrm{NH}^{+} \cdot \mathrm{SLS}^{-}\right]_{\mathrm{org}}$ (colorless). 
TABLE 1: Evaluation of intraday and interday precision and accuracy.

\begin{tabular}{|c|c|c|c|c|c|c|c|}
\hline \multirow{2}{*}{ Method } & \multirow{2}{*}{$\mathrm{CPH}$ taken $\mathrm{mg}$} & \multicolumn{3}{|c|}{ Intraday $(n=7)$} & \multicolumn{3}{|c|}{ Interday $(n=5)$} \\
\hline & & $\mathrm{CPH}$ found ${ }^{\mathrm{a}}$ & Precision $^{\mathrm{b}}$ & Accuracy ${ }^{\mathrm{c}}$ & $\mathrm{CPH}$ found ${ }^{\mathrm{a}}$ & Precision $^{\mathrm{b}}$ & Accuracy ${ }^{\mathrm{c}}$ \\
\hline \multirow{3}{*}{ Method A } & 6.0 & 6.04 & 1.08 & 0.65 & 6.08 & 1.68 & 0.87 \\
\hline & 12.0 & 12.20 & 0.96 & 1.32 & 12.24 & 1.17 & 1.48 \\
\hline & 18.0 & 18.12 & 1.18 & 1.24 & 18.15 & 1.33 & 1.36 \\
\hline \multirow{3}{*}{ Method B } & 4.0 & 4.06 & 1.29 & 1.08 & 4.09 & 1.36 & 1.45 \\
\hline & 6.0 & 6.16 & 1.92 & 1.78 & 6.18 & 2.08 & 1.62 \\
\hline & 8.0 & 8.14 & 1.75 & 1.44 & 8.16 & 1.92 & 1.75 \\
\hline
\end{tabular}

${ }^{a}$ Mean value of $n$ determinations.

${ }^{\mathrm{b}}$ Relative standard deviation (\%).

${ }^{\mathrm{c}} \operatorname{Bias}(\%)$ : [(found - taken)/taken] $\times 100$.

After the equivalence point:

$$
\begin{aligned}
& \mathrm{DMY}_{\text {org }}(\text { yellow })+\mathrm{H}^{+}+\mathrm{SLS}^{-} \\
& \longrightarrow\left[\mathrm{DMYH}^{+} \cdot \mathrm{SLS}^{-}\right]_{\text {org }}(\text { pink }) .
\end{aligned}
$$

3.1.2. Method B. This is based on the formation of an ionpair complex between the $\mathrm{CPH}$ and TPB as titrant in a solution buffered at $\mathrm{pH} 4.5$ using TBPE as indicator and 1,2dichloroethane as extracting solvent. The complex formed in this method is highly $\mathrm{pH}$ dependent, so the effect of $\mathrm{pH}$ was studied carefully and it was found that $5 \mathrm{~mL}$ of Walpole buffer of $\mathrm{pH} 4.5 \mathrm{in}$ a total volume of $10 \mathrm{~mL}$ of aqueous phase and $10 \mathrm{~mL}$ DCE solvent gave the best end-points and most consistent titers than chloroform or DCM.

The chemical reactions for this titration can be explained as follows.

Before adding the titrant:

$$
\begin{aligned}
& \mathrm{R}_{3} \mathrm{NH}^{+} \text {(colorless) }+\mathrm{TBPE}^{-} \text {(blue) } \\
& \stackrel{\mathrm{DCE}}{\longrightarrow}\left[\mathrm{R}_{3} \mathrm{NH}^{+} \cdot \mathrm{TBPE}^{-}\right]_{\text {org }} \text { (red-violet). }
\end{aligned}
$$

Before the equivalence point:

$$
\begin{aligned}
& \mathrm{R}_{3} \mathrm{NH}^{+}+\text {Titrant }^{-} \text {(colorless) } \\
& \longrightarrow\left[\mathrm{R}_{3} \mathrm{NH}^{+} \cdot \text { Titrant }^{-}\right]_{\text {org }} \text { (colorless). }
\end{aligned}
$$

After the equivalence point:

$$
\begin{aligned}
& \text { Titrant }^{-}+\mathrm{H}^{+}+\left[\mathrm{R}_{3} \mathrm{NH}^{+} \cdot \mathrm{TBPE}^{-}\right]_{\text {org }} \text { (red-violet) } \\
& \longrightarrow\left[\text { Titrant }^{-} \cdot \mathrm{R}_{3} \mathrm{NH}^{+}\right]_{\text {org }}+\mathrm{TBPEH} \text { (yellow) }
\end{aligned}
$$

When the mixture of CPH solution, buffer, DCE, and TBPE indicator solution was mixed well, the aqueous phase became colorless, and a red-violet color developed in the DCE phase, because the indicator forms an organophilic ionpair complex with the drug. When the drug sample was titrated with TPB solution, the protonated drug $\left(\mathrm{R}_{3} \mathrm{NH}^{+}\right)$ formed colorless ion association $\left(\mathrm{R}_{3} \mathrm{NH}^{+} \cdot\right.$ Titrant $\left.{ }^{-}\right)$which will be extracted into the organic phase. Near the equivalence point of the titration, the organic phase starts to turn green and when one drop excess of the titrant was added, the color of the organic phase changed from red-violet to yellow due to the formation of molecular form of the indicator, that is, TBPEH, Scheme 1.
3.1.3. Method Validation. The validation of the methods was done according to the present ICH guidelines [43].

3.1.4. Range and Stoichiometry. The proposed procedures are applicable over the ranges of 1.0-20 and $2.0-9.0 \mathrm{mg}$ of $\mathrm{CTH}$ for method $\mathrm{A}$ and method $\mathrm{B}$, respectively. The reaction stoichiometry was calculated to be $1: 1$ for both methods $(\mathrm{CPH}: \mathrm{SLS})$ in method $\mathrm{A}$ and $(\mathrm{CPH}: \mathrm{TPB})$ in method $\mathrm{B}$, owing to the presence of one basic nitrogen atom in the $\mathrm{CPH}$.

3.1.5. Accuracy and Precision. Accuracy of an analytical method expresses the closeness between the reference and the found values. Accuracy was evaluated as percentage relative error between the measured and taken amounts of $\mathrm{CPH}$ (Bias \%). The results, compiled in Table 1, show that the accuracy is good for both methods. Precision of the methods was calculated in terms of intermediate precision (intraday and interday). Three different amounts of $\mathrm{CPH}$ (within the working limits) were analyzed in seven replicates during the same day (intraday precision) and five consecutive days (interday precision). RSD (\%) values of the intraday and interday studies showed that the precision was good for both methods, too (Table 1).

3.1.6. Selectivity. To determine the selectivity of the methods, the analytical placebo was prepared and subjected to analysis by the proposed methods. It was confirmed that the change in the titrant value with respect to the water blank was caused only by the analyte. To identify the interference by common tablet excipients, a synthetic mixture with the composition: CPH (100 mg), talc ( $80 \mathrm{mg})$, starch (100 mg), calcium gluconate $(60 \mathrm{mg})$, lactose $(80 \mathrm{mg})$, sodium alginate (60 $\mathrm{mg}$ ), and magnesium stearate $(90 \mathrm{mg})$, was prepared and subjected to analysis by the proposed methods after solution preparation using the procedure described earlier. The percent recoveries of $\mathrm{CPH}$ were $98.46 \pm 1.64(n=5)$ and $99.41 \pm 1.21(n=5)$ by methods A and B, respectively, suggesting no interference by the excipients in the assay of $\mathrm{CPH}$ under the described optimum conditions.

3.1.7. Robustness and Ruggedness of the Methods. The robustness of the methods was evaluated by making small incremental changes in volumes of $\mathrm{H}_{2} \mathrm{SO}_{4}(2 \pm 0.5 \mathrm{~mL})$ and $\mathrm{CHCl}_{3}(10 \pm 1 \mathrm{~mL})$ in method $\mathrm{A}$, Walpole Buffer of 
TABLE 2: Comparison of assay results of proposed and reference methods.

\begin{tabular}{|c|c|c|c|c|}
\hline \multirow{3}{*}{ Tablet brand name } & \multirow{3}{*}{ Nominal amount, mg } & \multicolumn{3}{|c|}{ Found $(\% \text { of nominal amount } \pm \mathrm{SD})^{*}$} \\
\hline & & \multirow[t]{2}{*}{ Reference method } & \multicolumn{2}{|c|}{ Proposed methods } \\
\hline & & & Method A & Method B \\
\hline \multirow{3}{*}{ Practin $^{\mathrm{a}}$} & & & $98.86 \pm 1.04$ & $99.48 \pm 1.12$ \\
\hline & 4 & $100.3 \pm 0.76$ & $t=3.3$ & $t=2.9$ \\
\hline & & & $F=4.5$ & $F=5.2$ \\
\hline \multirow{3}{*}{ Ciplactin $^{\mathrm{b}}$} & & & $98.76 \pm 1.87$ & $99.26 \pm 2.00$ \\
\hline & 4 & $100.8 \pm 0.85$ & $t=3.6$ & $t=3.2$ \\
\hline & & & $F=3.5$ & $F=4.3$ \\
\hline
\end{tabular}

* Mean value of five determinations.

** Marketed by: ${ }^{\mathrm{a}}$ Wockhardt Ltd., India, ${ }^{\mathrm{b}}$ Cipla India Ltd., India.

Tabulated $t$ value at the $95 \%$ confidence level is 2.78 ; tabulated $F$ value at the $95 \%$ confidence level is 6.39 .

TABLE 3: Results of recovery study using the standard-addition method.

\begin{tabular}{lcccccccc}
\hline & \multicolumn{4}{c}{ Method A } \\
$\begin{array}{l}\text { Formulation } \\
\text { studied }\end{array}$ & $\begin{array}{c}\text { CPH in } \\
\text { tablet, mg }\end{array}$ & $\begin{array}{c}\text { Pure CPH } \\
\text { added, mg }\end{array}$ & $\begin{array}{c}\text { Total } \\
\text { found, } \\
\text { mg }\end{array}$ & $\begin{array}{c}\text { Pure CPH } \\
\text { recovered*, } \\
\text { percent } \pm \text { SD }\end{array}$ & $\begin{array}{c}\text { CPH in } \\
\text { tablet, mg }\end{array}$ & $\begin{array}{c}\text { Pure CPH } \\
\text { added, mg }\end{array}$ & $\begin{array}{c}\text { Total } \\
\text { found, } \\
\text { mg }\end{array}$ & $\begin{array}{c}\text { Pure CPH recovered*, } \\
\text { percent } \pm \text { SD }\end{array}$ \\
\hline \multirow{3}{*}{ Practin } & 7.90 & 4.0 & 11.86 & $99.26 \pm 1.11$ & 2.98 & 1.5 & 4.49 & $99.33 \pm 1.06$ \\
& 7.90 & 8.0 & 16.15 & $103.22 \pm 1.82$ & 2.98 & 3.0 & 6.10 & $102.3 \pm 1.97$ \\
& 7.90 & 12.0 & 19.83 & $99.35 \pm 0.98$ & 2.98 & 4.5 & 7.55 & $101.8 \pm 1.01$ \\
\hline \multirow{3}{*}{ Ciplactin } & 5.92 & 3.0 & 8.96 & $101.72 \pm 1.45$ & 2.96 & 1.5 & 4.40 & $99.25 \pm 1.26$ \\
& 5.92 & 6.0 & 11.97 & $100.85 \pm 1.68$ & 2.96 & 3.0 & 6.16 & $101.92 \pm 1.63$ \\
& 5.92 & 9.0 & 15.22 & $103.07 \pm 2.07$ & 2.96 & 4.5 & 7.72 & $102.04 \pm 1.12$ \\
\hline
\end{tabular}

* Mean value of three determinations.

$\mathrm{pH} 4.5(5 \pm 0.5 \mathrm{~mL})$ and $\mathrm{DCE}(10 \pm 1 \mathrm{~mL})$ in method $\mathrm{B}$ and the effect of the changes was studied by calculating the RSD values. The changes had negligible influence on the results as revealed by small intermediate precision values expressed as $\%$ RSD. The values were lying in the range $1.35-2.85 \%$.

Method ruggedness was expressed as the RSD of the same procedure applied by four different analysts as well as using four different burettes. The interanalysts RSD were within $2.65 \%$ whereas the interburettes RSD for the same $\mathrm{CPH}$ amount were ranged from 1.54 to $3.35 \%$ suggesting that the developed method was rugged.

3.1.8. Application to Tablets. The proposed methods were successfully applied to the determination of $\mathrm{CPH}$ in two representative tablets Practin and Ciplactin. The results obtained are shown in Table 2 and were compared with those obtained by the reference method [3] by means of Student's $t$ - and $F$-tests [44] at 95\% confidence level. The reference method consisted of the measurement of the absorbance of $\mathrm{CPH}$ tablet extract $0.1 \mathrm{M} \mathrm{HCl}$ at $286 \mathrm{~nm}$. In all the cases, the average results obtained by the proposed methods and reference method were statistically identical, as the difference between the average values were not significant at $95 \%$ confidence level with respect to accuracy and precision. Accuracy of the proposed methods was further confirmed using the standard addition procedure. Preanalyzed tablet powder was spiked with pure CPH at three different levels $(50,100$, and $150 \%$ of the quantity present in the tablet powder) and the total was measured by the proposed methods. The determination with each amount was repeated three times and the results of this study presented in Table 3 indicated that the various excipients present in the formulations did not interfere in the assay.

\section{Conclusions}

Two useful methods for the determination of $\mathrm{CPH}$ were developed, optimized, and validated based on ion-pair extraction titration. The ion-pair extraction titrimetry would be convenient for use in the laboratory, because with it, there is no need for sophisticated instrumentation. The proposed methods are simple, accurate, rapid, and cheaper than the reported chromatographic methods. The procedures do not involve any critical reaction conditions or tedious sample preparation. Among the two proposed methods, method A is more convenient as the end point detection is very clear and with a wide range (1-20 mg) than method $B$, which involves addition of buffer and a narrow range (2-9 mg). The wide applicability of the proposed procedures for routine quality control is well established by the assay of $\mathrm{CPH}$ in pure form and in pharmaceutical preparations.

\section{Acknowledgments}

The authors thank Cipla India Ltd., Bangalore, India, for gifting pure cyproheptadine hydrochloride. Authors are grateful 
to thank the authorities of the University of Mysore, Mysore, for permission and facilities.

\section{References}

[1] S. C. Sweetman, Martindale-The Complete Drug Reference, Pharmaceutical Press, London, UK, 33rd edition, 2002.

[2] A. Jez and M. Gorezyea, Chemia Lekow, PZWL, 1998.

[3] The Indian Pharmacopoeia, vol. I, Govt of India, Ministry of Health and Family Welfare, New Delhi, India, 1996.

[4] The United States Pharmacopoeia XXIV Revision, The National Formulary XIX Rockville, USP Convention, 2000.

[5] X. Feás, L. Ye, S. V. Hosseini, C. A. Fente, and A. Cepeda, "Development and validation of LC-MS/MS method for the determination of cyproheptadine in several pharmaceutical syrup formulations," Journal of Pharmaceutical and Biomedical Analysis, vol. 50, no. 5, pp. 1044-1049, 2009.

[6] C. Yang and Q. Men, "Determination of the content of cyperheptadine hydrochloride tablets by gas chromatography," Yaowu Fenxi Zazhi, vol. 11, no. 2, pp. 113-118, 1991.

[7] R. T. Sane, P. P. Karkhanis, and P. G. Anaokar, "Gas chromatographic estimation of cyproheptadine in pharmaceuticals," Indian Journal of Pharmaceutical Sciences, vol. 43, no. 3, pp. 111-112, 1981.

[8] A. D. Mao and B. F. Wang, "Determination of cyproheptadine hydrochloride in tablets by reversed-phase HPLC," Yaowu Fenxi Zazhi, vol. 21, no. 1, pp. 60-61, 2001.

[9] P. A. Williams, "Compendial monograph evaluation and development: cyproheptadine hydrochloride. Report of findings and recommendations on the monographs for cyproheptadine hydrochloride, cyproheptadine hydrochloride syrup, and cyproheptadine hydrochloride tablets," Pharmacopeial Forum, vol. 14, no. 1, pp. 3463-3472, 1988.

[10] G. R. Rao and S. Raghuveer, "High-pressure liquid-chromatographic determination of cyproheptadine hydrochloride in dosage forms," Indian Drugs, vol. 22, no. 7, pp. 377-380, 1985.

[11] G. W. Burrows and C. L. Alliger, "High-performance liquid chromatographic determination of cyproheptadine hydrochloride in tablet formulations," Journal of Pharmaceutical Sciences, vol. 72, no. 10, pp. 1212-1213, 1983.

[12] K. Basavaiah, V. S. Charan, U. chandrashekar, P. Nagegowda, and B. C. Somashekar, "Isocratic high-performance liquid chromatographic determination of cyproheptadine hydrochloride in tablet," Bulgarian Chemical Communications, vol. 36, no. 2, pp. 112-116, 2004.

[13] Z. Lingya, "Determination of cyproheptadine hydrochloride tablets by HPLC," China Pharmacis, vol. 09, 2009.

[14] A. El-Gindy, F. El-Yazby, A. Mostafa, and M. M. Maher, "HPLC and chemometric methods for the simultaneous determination of cyproheptadine hydrochloride, multivitamins, and sorbic acid," Journal of Pharmaceutical and Biomedical Analysis, vol. 35, no. 4, pp. 703-713, 2004.

[15] C. Ying, J. Yin, and Z. Wengang, "Determination for cyproheptadine in feedstuff by HPLC," China Feed, vol. 2, 2011.

[16] S. Adamski, "Extractive spectrophotometric determination of cyproheptadine hydrochloride using bromocresol green," Acta Poloniae Pharmceutica, vol. 22, pp. 311-314, 1965.

[17] J. Emmanuel and T. V. Yegnanarayan, "Colorimetric estimation of cyproheptadine hydrochloride," Indian Drugs, vol. 19, no. 12 , pp. 505-507, 1982.

[18] R. T. Sane, U. M. Vaidya, V. G. Nayak et al., "Use of three dyes for the spectrophotometric determination of cyproheptadine hydrochloride," Indian Drugs, vol. 19, no. 12, pp. 398-403, 1982.

[19] C. N. Carducci, G. Barcic, and A. Mascaro, "Spectrophotometric determination of antihistamines with benzyl orange," Application to Drugs, SAFYBI, vol. 19, pp. 1358-1361, 1979.

[20] K. Basavaiah and V. S. Charan, "Ion-pair complexometric determination of cyproheptadine hydrochloride using bromophenol blue," Science Asia, vol. 30, pp. 163-170, 2004.

[21] K. Basavaiah and V. S. Charan, "The use of chloranilic acid for the spectrophotometric determination of three antihistamines," Turkish Journal of Chemistry, vol. 26, no. 5, pp. 653661, 2002.

[22] D. M. Shingbal and S. D. Naik, "Determination of cyproheptadine hydrochloride by complexation," Indian Drugs, vol. 18, pp. 444-446, 1981.

[23] K. Basavaiah, "Application of bromate-bromide mixture and methyl orange in the titrimetric, spectrophotometric and kinetic assay methods for cyproheptadine in pharmaceuticals," Indian Journal of Chemical Technology, vol. 13, no. 4, pp. 360366, 2006.

[24] X. Zhou, "Simultaneous determination of two components in cyproheptadine hydrochloride tablets by uvspectrophotometry," Zhongguo Yaoke Daxue Xuebao, vol. 20, pp. 307-308, 1989.

[25] Y. M. Issa, M. S. Rizk, and S. S. Mohammed, "Performance and characteristics of new cyproheptadine hydrochloride-selective plastic membrane electrodes based on cyproheptadine tetraphenylborate," Analytical Letters, vol. 25, no. 9, pp. 16171619, 1992.

[26] A. A. Bunaciu, M. S Ioneseu, I. Enacheseu, G. E. Baiuleseu, and V. V. Cosofret, "Cyproheptadine-membrane electrode and its use in pharmaceutical analysis," Analusis, vol. 16, no. 1, pp. 131-134, 1988.

[27] J. Drozd and H. Hopkala, "Cyproheptadine ion-selective electrodes and their applications in some pharmaceutical formulations," Desalination, vol. 163, no. 1-3, pp. 119-125, 2004.

[28] R. X. Liu and J. R. Lü, "Determination of cyproheptadine hydrochloride with riboflavin chemiluminescence system," Fenxi Huaxue/ Chinese Journal of Analytical Chemistry, vol. 37, no. 2, pp. 267-270, 2009.

[29] S. Feng and L. Guo, "Sensitive determination of nitrogenous hydrochloride drugs via their reaction with ammonium molybdate," Chemical Papers, vol. 62, no. 4, pp. 350-357, 2008.

[30] The British Pharmacopeia 2009, vol. I/II, Her Majesty's Stationary Office, London, UK, 2009.

[31] A. M. A. Sameer and K. Basavaiah, "Application of ion-association titration for the assay of bupropion hydrochloride in pharmaceuticals," Chemical Industry and Chemical Engineering Quarterly, vol. 17, no. 3, pp. 299-306, 2011.

[32] T. Sakai, "Stepwise determination of quaternary ammonium salts and aromatic amines in pharmaceuticals by ion association titration," Analytical Sciences, vol. 17, no. 12, pp. 13791382, 2001.

[33] T. Sakai, N. Teshima, and Y. Takatori, "Ion association titration for the determination of local anesthetics in pharmaceuticals with tetrabromophenolphthalein ethyl ester as an indicator," Analytical Sciences, vol. 17, no. 9, pp. 1105-1107, 2001.

[34] I. C. Constantinescu, M. Florea, C. C. Aramă, A. Nedelcu, and C. M. Monciu, "Assay of nimesulide by ion association titration," Farmacia, vol. 57, no. 3, pp. 267-271, 2009.

[35] P. Crina-Maria, N. Angela, A. Corina, and N. Alexandra, "Contribuţii la determinarea cantitativă a cinarizinei şi dipiridamolului. Nota I. Noi metode titrimetrice," Farmacia, vol. 46, pp. 29-34, 1998. 
[36] P. Crina-Maria, N. Angela, A. Corina, and N. Alexandra, "Contribuții la determinarea cantitativă a maleatului de timolol, cilazaprilului şi bromhexinului. Noi metode titrimetrice," Farmacia, vol. 43, pp. 15-21, 1995.

[37] N. Rajendraprasad, K. Basavaiah, and K. B. Vinay, "Ion-pair titrimetric assays of quetiapine fumarate in pharmaceuticals using sodium traphenylboron and sodium lauryl sulphate," Thai Journal Pharmaceutical Science, vol. 35, no. 2, pp. 89-97, 2011.

[38] R. Tyagi, V. K. Tyagi, and R. K. Khanna, "Synthesis, characterization and performance of tallow fatty acids and triethanolamine based esterquats," Journal of Oleo Science, vol. 55, no. 7, pp. 337-345, 2006.

[39] M. Tsubochi, "The determination of berberine by Ion-pair extraction-titration, with tetrabromophenolphthalein ethyl ester as the indicator," Bulletin of Chemical Society of Japan, vol. 52, pp. 2581-2583, 1979.

[40] D. C. Cullum, Introduction to Surfactant Analysis, Blackie Academic and Professional, Glasgow, UK, 1994.

[41] M. Tsubochi, N. Yamasaki, and K. Matsuoka, "Determination of anionic surfactants by two-phase titration with tetrabromophenolphthalein ethyl ester as indicator," Journal of the American Oil Chemists' Society, vol. 56, no. 11, pp. 921-923, 1979.

[42] G. Eppert and G. Liebscher, "Two-phase titration for determination of anionic surfactants," (in German). Zournal of Chemistry, vol. 18, pp. 188-189, 1978.

[43] International Conference on Hormonisation of Technical Requirements for Registration of Pharmaceuticals for Human Use, ICH Harmonised Tripartite Guideline, Validation of Analytical Procedures: Text and Methodology Q2(R 1), Complementary Guideline on Methodology dated 06 November 1996, London, UK, November 2005.

[44] J. Inczedy, T. Lengyel, and A. M. Ure, IUPAC Compendium of Analytical Nomenclature: Definitive Rules, Blackwell Science, Boston, Mass, USA, 1998. 


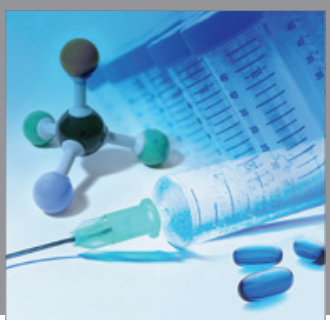

International Journal of

Medicinal Chemistry

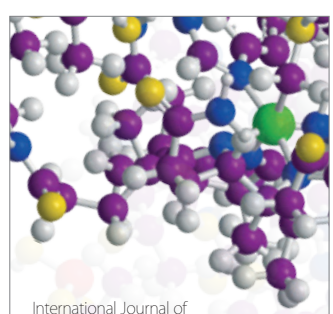

Carbohydrate Chemistry

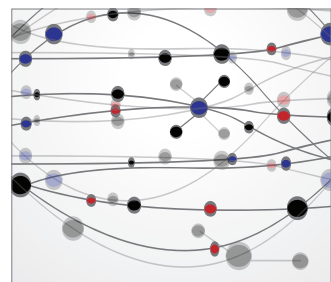

The Scientific World Journal
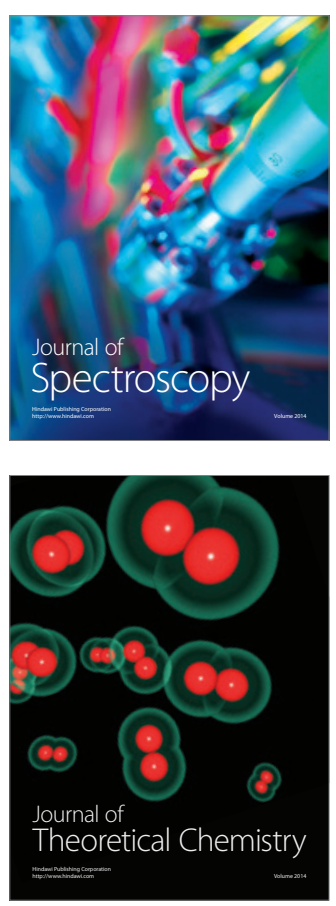
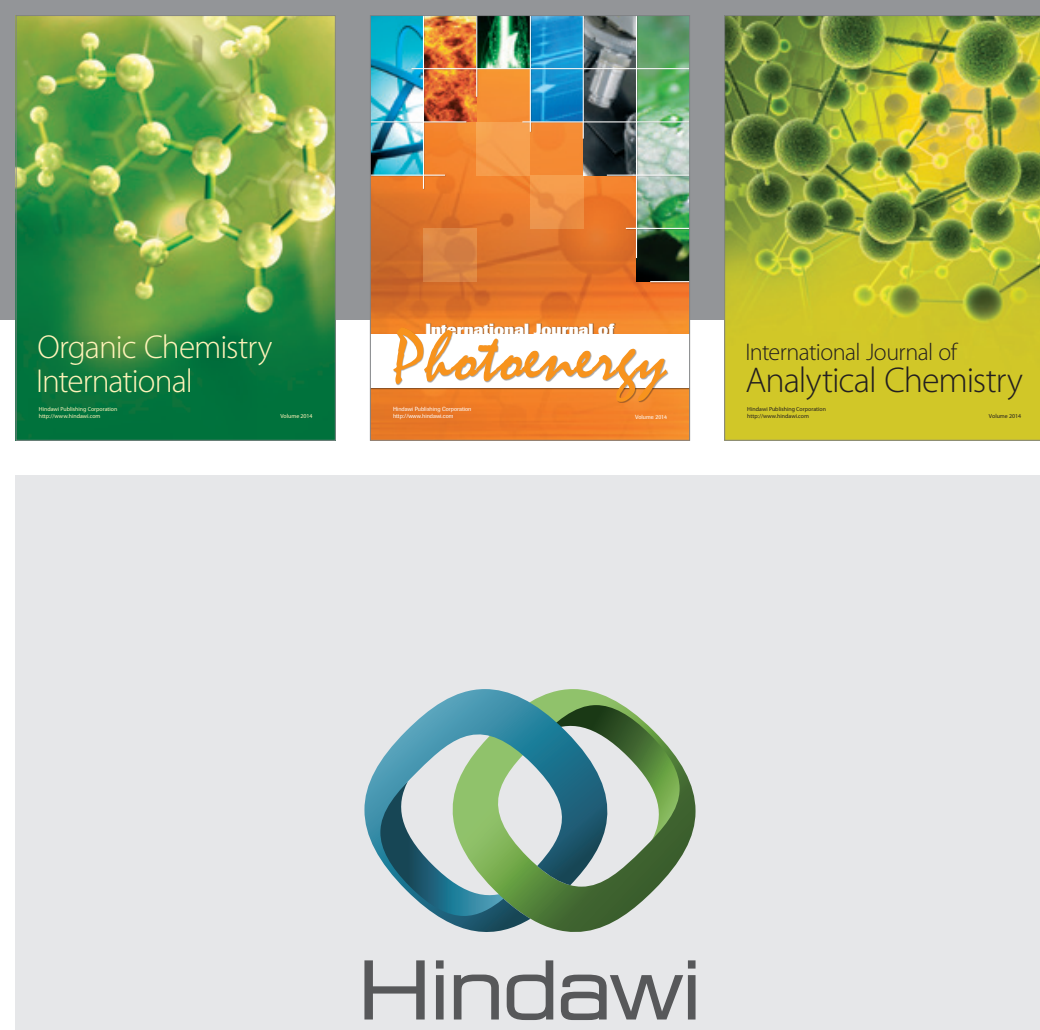

Submit your manuscripts at

http://www.hindawi.com
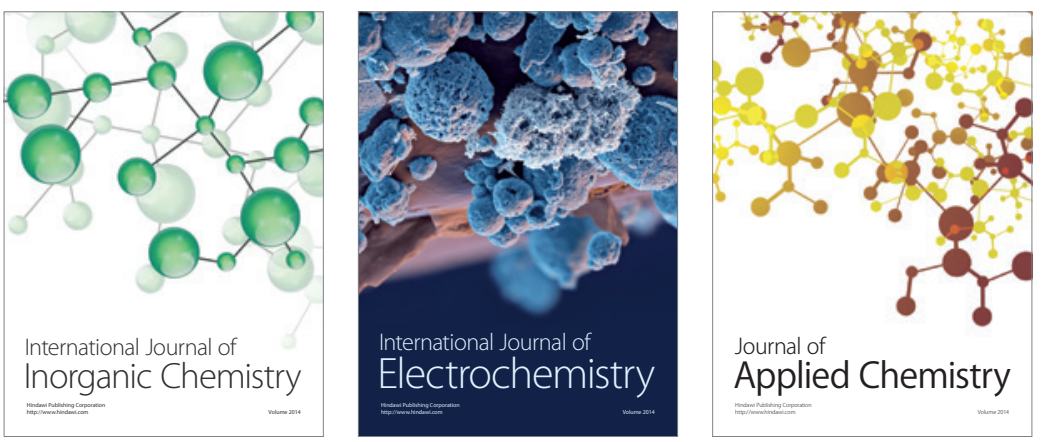

Journal of

Applied Chemistry
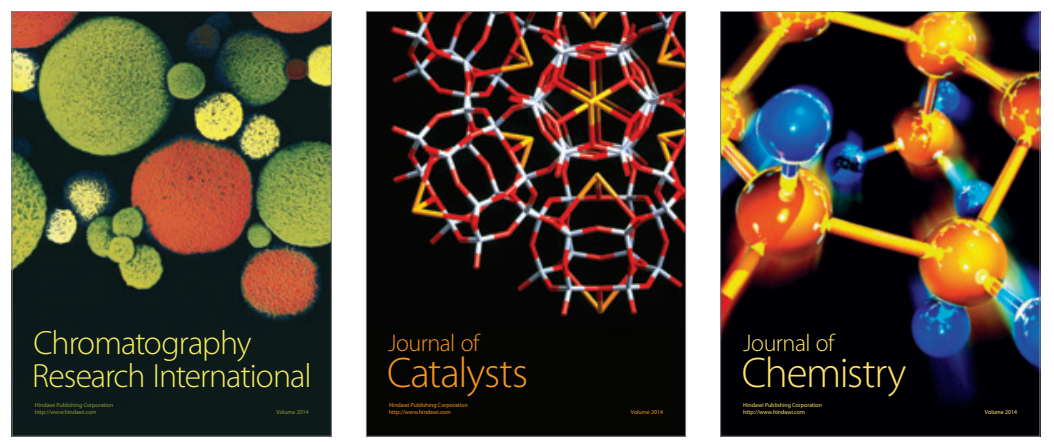
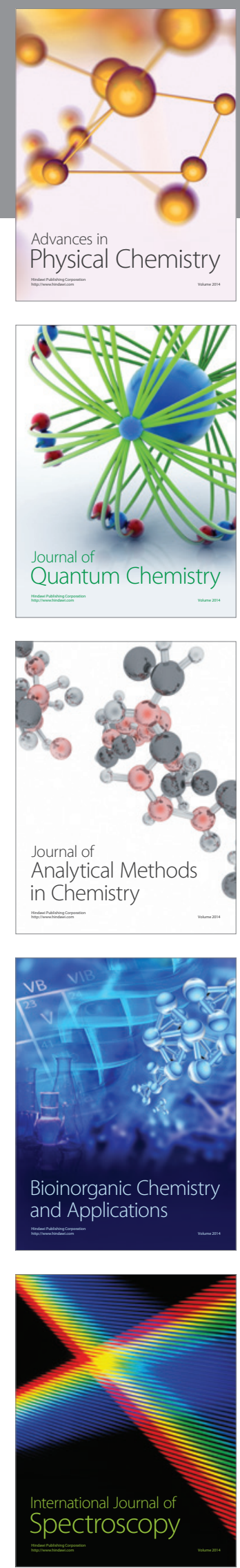